\title{
Fluctuations of a Greenlandic tidewater glacier driven by changes in atmospheric forcing: observations and modelling of Kangiata Nunaata Sermia, 1859-present
}

\author{
J. M. Lea ${ }^{1, *}$, D. W. F. Mair ${ }^{1}$, F. M. Nick ${ }^{2,3}$, B. R. Rea ${ }^{1}$, D. van As ${ }^{4}$, M. Morlighem ${ }^{5}$, P. W. Nienow ${ }^{6}$, and A. Weidick ${ }^{4}$ \\ ${ }^{1}$ Department of Geography and the Environment, University of Aberdeen, Elphinstone Road, Aberdeen AB24 3UF, UK \\ ${ }^{2}$ The University Centre in Svalbard (UNIS), P.O. Box 156, 9171 Longyearbyen, Norway \\ ${ }^{3}$ Centre for Ice and Climate, Niels Bohr Institute, University of Copenhagen, 2100 Copenhagen, Denmark \\ ${ }^{4}$ Geological Survey of Denmark and Greenland (GEUS), Copenhagen, Denmark \\ ${ }^{5}$ University of California, Irvine, Department of Earth System Science, Croul Hall, Irvine, CA 92697-3100, USA \\ ${ }^{6}$ Department of Geography, University of Edinburgh, Drummond Street, Edinburgh EH8 9XP, UK \\ *now at: Department of Geography and Quaternary Geology, Stockholm University, 10691 Stockholm, Sweden
}

Correspondence to: J. M. Lea (james.lea@ natgeo.su.se)

Received: 4 April 2014 - Published in The Cryosphere Discuss.: 24 April 2014

Revised: 4 September 2014 - Accepted: 22 September 2014 - Published: 5 November 2014

\begin{abstract}
Many tidewater glaciers in Greenland are known to have undergone significant retreat during the last century following their Little Ice Age maxima. Where it is possible to reconstruct glacier change over this period, they provide excellent records for comparison to climate records, as well as calibration/validation for numerical models. These glacier change records therefore allow for tests of numerical models that seek to simulate tidewater glacier behaviour over multi-decadal to centennial timescales. Here we present a detailed record of behaviour from Kangiata Nunaata Sermia (KNS), SW Greenland, between 1859 and 2012, and compare it against available oceanographic and atmospheric temperature data between 1871 and 2012. We also use these records to evaluate the ability of a well-established onedimensional flow-band model to replicate behaviour for the observation period. The record of terminus change demonstrates that KNS has advanced/retreated in phase with atmosphere and ocean climate anomalies averaged over multiannual to decadal timescales. Results from an ensemble of model runs demonstrate that observed dynamics can be replicated. Model runs that provide a reasonable match to observations always require a significant atmospheric forcing component, but do not necessarily require an oceanic forcing component. Although the importance of oceanic forcing cannot be discounted, these results demonstrate that changes in
\end{abstract}

atmospheric forcing are likely to be a primary driver of the terminus fluctuations of KNS from 1859 to 2012. We propose that the detail and length of the record presented makes KNS an ideal site for model validation exercises investigating links between climate, calving rates, and tidewater glacier dynamics.

\section{Introduction}

Calving from tidewater glaciers (TWGs) presently accounts for up to $50 \%$ of the mass loss from the Greenland Ice Sheet (Van den Broeke et al., 2009). Determining controls on tidewater glacier dynamics over decadal to centennial timescales is crucial to understanding their contribution to sea level in a warming climate (Alley et al., 2010; Vieli and Nick, 2011). The ability to achieve this in Greenland has been restricted in part by the relative lack of TWG terminus observations prior to the satellite age, as well as evidence of terminus locations being spread across a disparate array of sources. However, the synthesis of these sources has previously allowed for multi-decadal to centennial records of TWG glacier behaviour to be reconstructed (e.g. Csatho et al., 2008; Bjørk et al., 2012; Weidick et al., 2012). 
Such records provide potentially excellent calibration and validation records for numerical modelling efforts (Vieli and Nick, 2011). That is to say, numerical models that are capable of replicating observed terminus behaviour over decadal to centennial timescales will be better placed to predict the future behaviour of a TWG over similar timescales. Despite this, there remain few examples of modelling efforts that have attempted to calibrate their results against multi-decadal observational records (e.g. Colgan et al., 2012). The ability of most numerical models to replicate dynamics over such timescales using realistic inputs therefore remains largely untested.

By undertaking calibration/validation exercises, the sensitivity of the terminus to different climatic forcing can also be evaluated (e.g. Nick et al., 2013; Cook et al., 2014; Lea et al., 2014a). This is achieved by comparing the sensitivity of a modelled glacier to climate forcing against observations (Nick et al., 2013). With a knowledge of realistic ranges of forcing, this allows for evaluation of the relative importance of each in contributing to the observed TWG behaviour.

Changes in oceanic forcing are significant drivers of TWG retreat in Greenland (Murray et al., 2010; Straneo et al., 2010; Rignot et al., 2012), but their relative importance between glaciers appears to be dependent on geographical location, glacier geometry (Nick et al., 2013), and potentially fjord connectivity with the open ocean (Straneo et al., 2012). Model-based studies have also helped to demonstrate the sensitivity of some major outlet glaciers to air temperature changes (via enhanced runoff increasing crevasse water depth; Nick et al., 2013; Cook et al., 2014).

Where multi-decadal to centennial timescale climate data exist alongside records of terminus position, these provide the potential for robust evaluation of both numerical models and the importance of different drivers of TWG terminus change. In this study we aim to (1) reconstruct the fluctuations of Kangiata Nunaata Sermia (KNS), SW Greenland, from 1859 to present, coinciding with the availability of climate records; (2) use these data to evaluate the ability of a well-established climate-driven numerical ice-flow model in order to replicate its dynamics; and (3), in conjunction with fjord topography data, assess controls on the terminus stability of KNS over multi-decadal to centennial timescales.

\section{Field site and climate data}

KNS is the largest TWG on the west coast of Greenland, south of Jakobshavn Isbræ (Fig. 1; Van As et al., 2014). It is known to have undergone significant retreat since its Little Ice Age maximum (Weidick et al., 2012), retreating a total of $22.6 \mathrm{~km}$, with at least $12 \mathrm{~km}$ of this retreat occurring prior to 1859 , when climate forcing data are unavailable (Lea et al., 2014a). It is situated $\sim 100 \mathrm{~km}$ inland from Nuuk at the head of Godthåbsfjord, and currently has a calving flux of $\sim 6 \mathrm{~km}^{3} \mathrm{a}^{-1}$ (Van As et al., 2014).

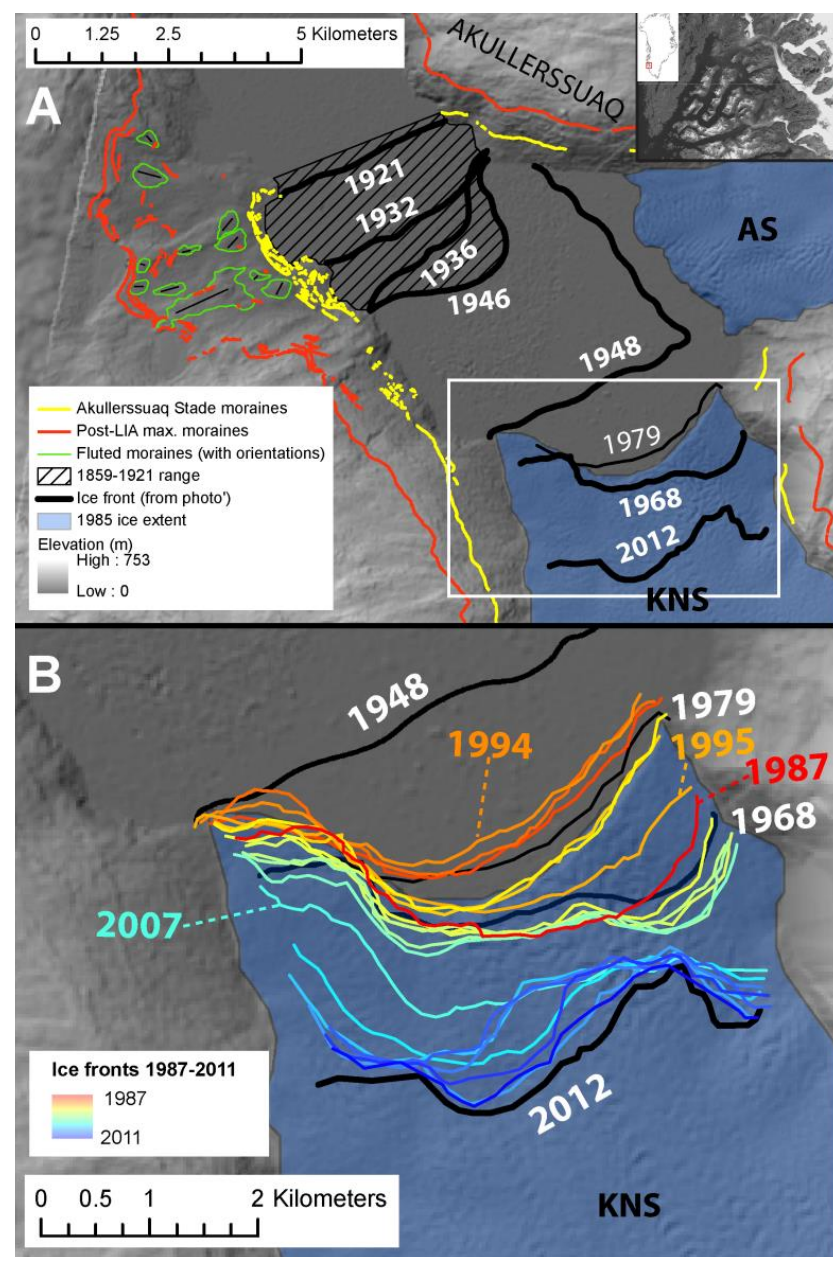

Figure 1. Diagrams showing the site location (inset), terminus positions, and geomorphology plotted on a hillshaded mosaic of a stereophotogrammetrically derived digital elevation model (DEM) from images acquired in 1985, and ASTER GDEM (Hvidegaard et al., 2012). (a) Termini and geomorphology for 1859-2012, with ASM limits delineated in yellow, and (b) a detailed view of termini for the period 1948-2012, with specific years labelled for reference.

A continuous record of mean monthly air temperature is available at Nuuk from 1866 to present (Vinther et al., 2006; Cappelen, 2012). Temperatures at Nuuk are known to be strongly correlated with those near to the terminus region of KNS throughout the year (Taurisano et al., 2004). For this reason, we take the Nuuk record as an indicator of the atmospheric forcing at KNS.

As with all TWGs around Greenland, there are no long observational records of fjord water temperatures adjacent to KNS, though detailed hydrographic studies of the fjord have been undertaken recently (Mortensen et al., 2011, 2013). A shallow $\sim 80 \mathrm{~m}$ sill at the entrance to Godthåbsfjord at Nuuk has been suggested to limit the connectivity of the fjord to warm ocean waters at depth. In fjords where shallow sills do not exist, the incursion of these warm ocean waters is thought 
to have significantly affected the stability of TWGs (Rignot et al., 2012; Straneo et al., 2012). The presence of the shallow sill in Godthåbsfjord also results in significant tidal mixing at the fjord entrance, allowing for sea surface waters to be incorporated at depth, which are then advected into the fjord (Mortensen et al., 2011). These intermediate-level mixed waters have been proposed to significantly influence the energy available for submarine melting at the termini of the TWGs in Godthåbsfjord (Mortensen et al., 2013).

Due to the impact of surface waters near the fjord entrance on the energy balance of the fjord (Mortensen et al., 2011, 2013), and the potentially restricted influence of warm coastal currents at depth (Straneo et al., 2012), we suggest that sea surface temperatures (SSTs) provide a good indicator of the relative oceanographic forcing affecting KNS. Such data have also been used previously to interrogate the role of oceanographic forcing on TWG stability where observations at depth are unavailable (e.g. McFadden et al., 2011; Bevan et al., 2012). The HadISST $11^{\circ} \times 1^{\circ}$ data set provides SST estimates for the period 1871-present (Rayner et al., 2003), with annual averages for the area immediately offshore from Nuuk (62 to $64^{\circ} \mathrm{N}, 51$ to $53^{\circ} \mathrm{W}$ ) used as an indicator of oceanographic conditions affecting Godthåbsfjord. Although the data used will in part be based on interpolation of observations (especially in the earlier part of the record), the data have been validated for west Greenland against independent records back to 1875 (Hanna et al., 2009). This therefore provides confidence in the results obtained from the HadISST1 data set.

\section{Glacier reconstruction data}

A combination of geomorphology, maps, photography (ground-based, oblique-aerial, and vertical aerial images), and satellite imagery are used to reconstruct the terminus dynamics of KNS. By 1859 KNS is known to have retreated between 12 and $15 \mathrm{~km}$ from its Little Ice Age (LIA) maximum extent (Lea et al., 2014a). The post-LIA maximum glacial geomorphology of KNS has been mapped, while previous analysis of a photograph taken in the 1850s, and a map published in 1859 places the terminus position somewhere inside the limit of a significant glacier readvance/stillstand (Lea et al., 2014a). We refer to this as the Akullersuaq Stade (after the headland that its maximum extent adjoins), previously referred to as the "1920 Stade" (Weidick et al., 2012). This event is renamed due to the uncertainty of the exact timing of the glacier maximum.

Where the full terminus cannot be observed in photographs, terminus position is determined indirectly using the GIS-based analyses described below, in conjunction with evidence from maps (e.g. Lea et al., 2014a). Subsequent to 1921, intermittent direct observations of the terminus are available, enabling mapping of terminus positions from imagery (list of sources in Table 1).
Table 1. List of terminus observations and acquisition dates.

\begin{tabular}{|c|c|c|}
\hline Acquisition date & Observation type & Source \\
\hline $1850 \mathrm{~s}$ & Terrestrial photo & $\begin{array}{l}\text { H. Rink (in Weidick } \\
\text { et al., 2012) }\end{array}$ \\
\hline 1859 & Map & Kleinschmidt (1859) \\
\hline 1860 & Map & Poulsen (1860) \\
\hline 1866 & Map & Rink (1866) \\
\hline 1866 & Map & Falbe (1866) \\
\hline 1885 & Map & Jensen (1885) \\
\hline 1880s? & Sketch (after photo) & Nansen (1890) \\
\hline 1903 & Terrestrial photo & $\begin{array}{l}\text { J. Møller } \\
\text { in Bruun (1917) }\end{array}$ \\
\hline 1921 & Terrestrial photo & $\begin{array}{l}\text { A. Nissen in } \\
\text { Weidick et al. (2012) }\end{array}$ \\
\hline 1932 & Terrestrial photo & $\begin{array}{l}\text { A. Roussell in } \\
\text { Roussell (1941) }\end{array}$ \\
\hline 27 Aug 1936 & Oblique photo & Weidick et al. (2012) \\
\hline 10 Aug 1946 & Oblique photo & Weidick et al. (2012) \\
\hline 20 Aug 1948 & Oblique photo & Weidick et al. (2012) \\
\hline 21 Jun 1965 & Terrestrial photo & Weidick et al. (2012) \\
\hline 16 Aug 1968 & Aerial photo & USGS \\
\hline 15 Sep 1979 & Terrestrial photo & Weidick et al. (2012) \\
\hline 15 Sep 1987 & Satellite & Landsat \\
\hline 19 Sep 1992 & Satellite & Landsat \\
\hline 30 Aug 1993 & Satellite & Landsat \\
\hline 18 Sep 1994 & Satellite & Landsat \\
\hline 14 Oct 1995 & Satellite & Landsat \\
\hline 14 Sep 1996 & Satellite & Landsat \\
\hline 1 Sep 1997 & Satellite & Landsat \\
\hline 15 Sep 1999 & Satellite & Landsat \\
\hline 18 Sep 2000 & Satellite & Landsat \\
\hline 22 Oct 2001 & Satellite & Landsat \\
\hline 23 Sep 2002 & Satellite & Landsat \\
\hline 9 Aug 2003 & Satellite & Landsat \\
\hline $12 \mathrm{Sep} 2004$ & Satellite & Landsat \\
\hline 24 Sep 2005 & Satellite & Landsat \\
\hline 18 Sep 2006 & Satellite & Landsat \\
\hline 27 Sep 2007 & Satellite & Landsat \\
\hline 23 Sep 2008 & Satellite & Landsat \\
\hline 19 Sep 2009 & Satellite & Landsat \\
\hline 13 Sep 2010 & Satellite & Landsat \\
\hline 16 Sep 2011 & Satellite & Landsat \\
\hline $18 \mathrm{Sep} 2012$ & Satellite & Landsat \\
\hline
\end{tabular}

Landsat panchromatic band imagery was used to map terminus positions for 1987-2012. Cloud-free Landsat scenes were selected for analysis, acquired as late in the melt season as possible, or just after its end. The start of November was used as the latest date from which images could be selected, since mélange in the fjord has been observed to freeze beyond this, causing the terminus to advance (Mortensen et al., 2011; Sole et al., 2011). The majority of images were acquired during September or October, though cloud-free images for 1993 and 2003 were only available for dates in August (30 August 1993 and 9 August 2003 respectively). No suitable images were available for the years 1988-1991 and 1998, meaning that annual resolution rates of terminus change were acquired for 1992-1997 and 1999-2012 (Table 1). 
For the entire length of the record, where more than 1 year separated terminus observations, annually averaged rates of change were calculated. This provides a continuous record of the trends in behaviour, as well as inter-annual variability of KNS for the period spanning 1859-2012. This behaviour could then be directly compared to atmospheric and oceanic climate data.

Each terminus position was quantified using an adaptation of the box method (Moon and Joughin, 2008; Howat and Eddy, 2011), called the curvilinear box method (CBM; see Lea et al., 2014b, for details). This has a marked advantage over the centreline tracking or standard box methods, as it is capable of accounting for changes in terminus geometry while also accurately tracking changes in fjord orientation (Lea et al, 2014b). Furthermore, the box used to calculate terminus change is always centred on the glacier/fjord centreline, which is also the flow line used for the numerical model. Consequently, terminus positions and observed changes in position derived using the CBM can be compared directly to model output.

\section{The TWG model}

The numerical model used is specifically designed to simulate the dynamics of TWGs along a flow band (Nick et al., 2010). It has been successful in replicating the dynamics of marine terminating outlets in both Greenland (e.g. Vieli and Nick, 2011; Nick et al., 2012; Lea et al., 2014a) and Antarctica (Jamieson et al., 2012, 2014), and has also been used to make centennial timescale projections of the future contribution of Greenland's major TWG outlets to global sea level (Nick et al., 2013). The model uses a stretched grid, allowing for a robust treatment of grounding line dynamics (Pattyn et al., 2012), while basal, lateral, and longitudinal shear stresses are accounted for. Bed topography data for the majority of the catchment are provided by Bamber et al. (2001), though the lower $40 \mathrm{~km}$ is generated using a mass-continuity-based bed reconstruction (Morlighem et al., 2011), validated against available OIB/CReSIS flight lines (Gogineni et al., 2001). Fjord width (Fig. 3c) is defined as the sum of the minimum linear distances from a point on the flow line to either side of the fjord (Fig. 3a). Where available, fjord bathymetry data are also used where KNS has retreated following its LIA maximum (Fig. 3c; Weidick et al., 2012). Sensitivity analyses conducted by Lea et al. (2014a; their Fig. 10) for this bed configuration demonstrated that the model exhibits broadly comparable patterns of retreat behaviour where bed elevation is varied within an uncertainty of $\pm 50 \mathrm{~m}$.

A constant height versus surface mass balance (SMB) relation is used to calculate SMB for the ablation zone of KNS (Eq. 1). This is derived from the average RACMO SMB model output for 1958-2007 (Van Angelen et al., 2013).
Table 2. List of parameters and constants used for running the model.

\begin{tabular}{lr}
\hline Parameter/constant & Value \\
\hline Ice density $-\rho_{i}$ & $900 \mathrm{~kg} \mathrm{~m}^{-3}$ \\
Meltwater density $-\rho_{\mathrm{W}}$ & $1000 \mathrm{~kg} \mathrm{~m}^{-3}$ \\
Proglacial water body density $-\rho_{\mathrm{p}}$ & $1028 \mathrm{~kg} \mathrm{~m}^{-3}$ \\
Gravitational acceleration $-g$ & $9.8 \mathrm{~m} \mathrm{~s}^{-2}$ \\
Friction exponent $-m$ & 3 \\
Friction parameters $-\mu$ and $\lambda$ & 1 \\
Glen's flow law exponent $-n$ & 3 \\
& $4.5 \times 10^{-17}$ \\
Glen's flow law coefficient $-A$ & $\mathrm{~Pa}^{-3} \mathrm{a}^{-1}\left(-5^{\circ} \mathrm{C}\right)$ \\
Grid size & $\sim 250 \mathrm{~m}$ \\
Time step & $0.005 \mathrm{a}$ \\
\hline
\end{tabular}

$b(x)=0.0018 \times h(x)-2.693$,

where $b(x)$ is the SMB for position $x$ (the along-flow coordinate) on the model flow line and $h(x)$ is the glacier elevation for position $x$ on the flow line. Due to the tendency for overestimation of accumulation in RACMO in this region (Van As et al., 2014), positive SMB values in the upstream section of the modelled glacier are prescribed to be lower than the RACMO output, allowing for the glacier to maintain its contemporary elevation profile. Irrespective of this, SMB forcing has previously been demonstrated to be of minimal importance to results of modelled TWG dynamics over the timescales that are being investigated (Lea et al., 2014a). The model is initialised using a glacier geometry approximating that of the Akullersuaq Stade maximum (ASM), derived from geomorphological mapping of associated trimlines (Fig. 1). Constants and parameter values used are summarised in Table 2, while the initial tuning procedure followed for this configuration is the same as that used by Lea et al. (2014a). Surface runoff (Van As et al., 2014), air temperature (JJA average), and SST (annual average) data are used to drive changes in crevasse water depth $\left(d_{\mathrm{w}}\right)$ and submarine melting $(M)$ respectively.

Although seasonal cycles in velocity are observed at KNS within $20 \mathrm{~km}$ of its terminus (Ahlstrøm et al., 2013), at locations $>35 \mathrm{~km}$ from the terminus these have been demonstrated to have negligible effect $(\sim 1 \%)$ on net annual motion (Sole et al., 2011). Given that the timescales of interest are annual to decadal, seasonal variability in basal and lateral sliding is therefore not included within the model experiments. The model uses an effective pressure sliding law, allowing for it to replicate a typical tidewater glacier velocity profile, accelerating towards its terminus. Two zones of constant basal roughness (upstream and downstream) are prescribed to allow for the model to replicate observed elevation and velocity profiles (Lea et al., 2014a). This also ensures that particular areas of the fjord are not biased towards advance/retreat behaviour. All parameters which control the 
model sensitivity to climate forcing are derived using the Monte Carlo methods described below.

\subsection{Relating crevasse water depth to air temperature}

Changes in the value of $d_{\mathrm{w}}$ have previously been related to runoff variability (e.g. Nick et al., 2010; Cook et al., 2012, 2014), and have been successfully used as a climate-linked forcing directly affecting terminus change (Nick et al., 2013). This is achieved via a physically based crevasse water depth calving criterion (Benn et al., 2007), where crevasse penetration depth, as well as potential for calving, is enhanced by $d_{\mathrm{w}}$. However, the only previously used scaling of surface runoff to $d_{\mathrm{w}}$ requires a baseline $d_{\mathrm{w}}$ value to be prescribed, which it cannot fall below (Nick et al., 2013, their Eq. S3). To remove the need to define a minimum $d_{\mathrm{w}}$ value at the beginning of each model run, we present a new, unrestricted parameterisation that relates seasonal changes in monthly surface runoff to $d_{\mathrm{w}}$, and allows for $d_{\mathrm{w}}$ to freely evolve due to changes in annual runoff (Eq. 2).

$d_{\mathrm{wNew}}=d_{\mathrm{wPrev}}+\alpha_{1}\left(R_{\text {year }} \beta_{\text {month }}-\frac{R_{\text {base }}}{12}\right)$,

where $d_{\mathrm{wNew}}$ is the new crevasse water depth for a particular month; $d_{\mathrm{wPrev}}$ is the crevasse water depth from the previous month; $\alpha_{1}$ is the coefficient relating crevasse water depth sensitivity to changes in runoff; $R_{\text {year }}$ represents total runoff for a given year $\left(\mathrm{Gt} \mathrm{yr}^{-1}\right) ; \beta_{\text {month }}$ is the fraction of annual runoff occurring in a particular month; and $R_{\text {base }}$ is a baseline/long-term average annual runoff total $\left(\mathrm{Gt} \mathrm{yr}^{-1}\right)$, equivalent to the annual volume of water that is either refrozen within the glacier or drains from the crevasse to the bed. This assumes that the rate of refreezing/drainage of water from crevasses is constant from year to year. Where annual runoff exceeds $R_{\text {base }}$, the average annual $d_{\mathrm{w}}$ will therefore increase, and where runoff falls below $R_{\text {base }}$, the average annual $d_{\mathrm{w}}$ will decrease. Dividing annual runoff into each month's contribution also allows for the direct incorporation of $d_{\mathrm{w}}$ 's seasonal variability. The value of $d_{\mathrm{w}}$ will therefore reach its annual minimum prior to the onset of the melt season, and peak in August. The coefficient $\alpha_{1}$ allows for the sensitivity of $d_{\mathrm{w}}$ to changes in runoff to be adjusted, and is used as a tuning parameter.

\subsection{Definition of $\beta_{\text {month }}$}

The fraction of annual runoff occurring in each month, $\beta_{\text {month }}$, is derived from analysis of each month's average runoff from the catchments of both KNS and Akullersuaq Sermia (AS) over the period 1960-2012, as given by highresolution SMB modelling of the region (Van As et al., 2014). The runoff values for KNS and AS are summed since the glaciers were confluent for much of the time since their LIA maximum, including a significant portion of the period of interest of this study (see below, and Wedick et al.,

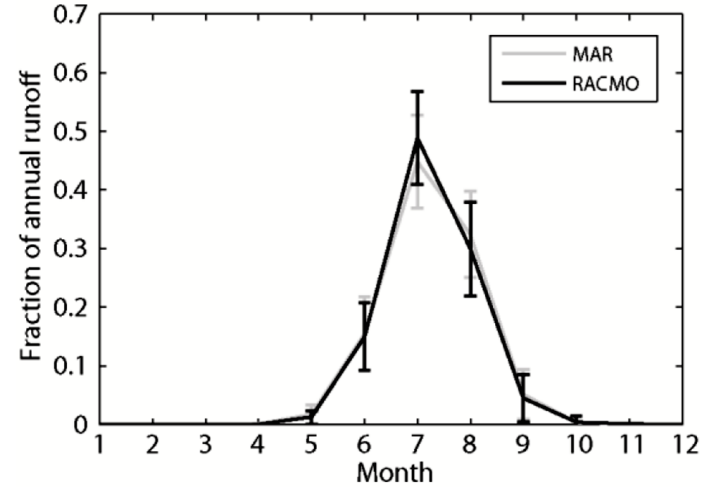

Figure 2. Fraction of annual runoff occurring for each month as given by MAR and RACMO2 SMB models for KNS and AS between 1960 and 2012 (Van As et al., 2014). Error bars are given to 2 standard deviations.

2012). Monthly runoff estimates were generated using both the Modèle Atmosphérique Régional (MARv3.2; Fettweis et al., 2011) and the Regional Atmospheric Climate Model (RACMO2; Van Angelen et al., 2013). The variability in the monthly fraction of annual runoff for the period 1960-2012 is shown for both models in Fig. 2, with each producing similar patterns and magnitudes of monthly variability. We took the median result from the monthly averages of the two models. This pattern of monthly variability was kept constant from year to year for each model run.

While the model can be forced directly with annual modelled runoff values for the period 1960-2012 (Van As et al., 2014), no such values are available for the century before. Runoff values prior to 1960 are therefore estimated using the relation that exists between average June-July-August (JJA) air temperatures $\left(A_{\mathrm{JJA}}\right)$ from Nuuk for 1960-2012 (Cappelen, 2012) and the modelled runoff values $(r=0.75)$. A regression equation is generated from this (Eq. 3), allowing for runoff estimates $\left(\mathrm{Gt} \mathrm{a}^{-1}\right)$ for the period 1866-1959 to be made from the Nuuk air temperature $\left({ }^{\circ} \mathrm{C}\right.$ ) record (Vinther et al., 2006; Cappelen et al., 2012).

$R_{\text {year }}=0.91 \times A_{\mathrm{JJA}}-1.53$

Combined with the 1960-2012 modelled values, this produces a continuous record of estimated annual runoff for 1871-2012. Average monthly variability in runoff is superimposed on this record using the $\beta_{\text {month }}$ term.

\subsection{Confluence with AS: adjustments to $d_{w}$ and ice flux}

While KNS and AS are confluent in model simulations, variability in $d_{\mathrm{w}}$ at the terminus is driven by total runoff values from both catchments. The confluence area of the two glaciers is defined on the model flow line as being $5 \mathrm{~km}$ across, lying between 4 and $9 \mathrm{~km}$ from the 2012 terminus position. However, as KNS retreats through the confluence with AS, the runoff contribution from AS to the terminus 

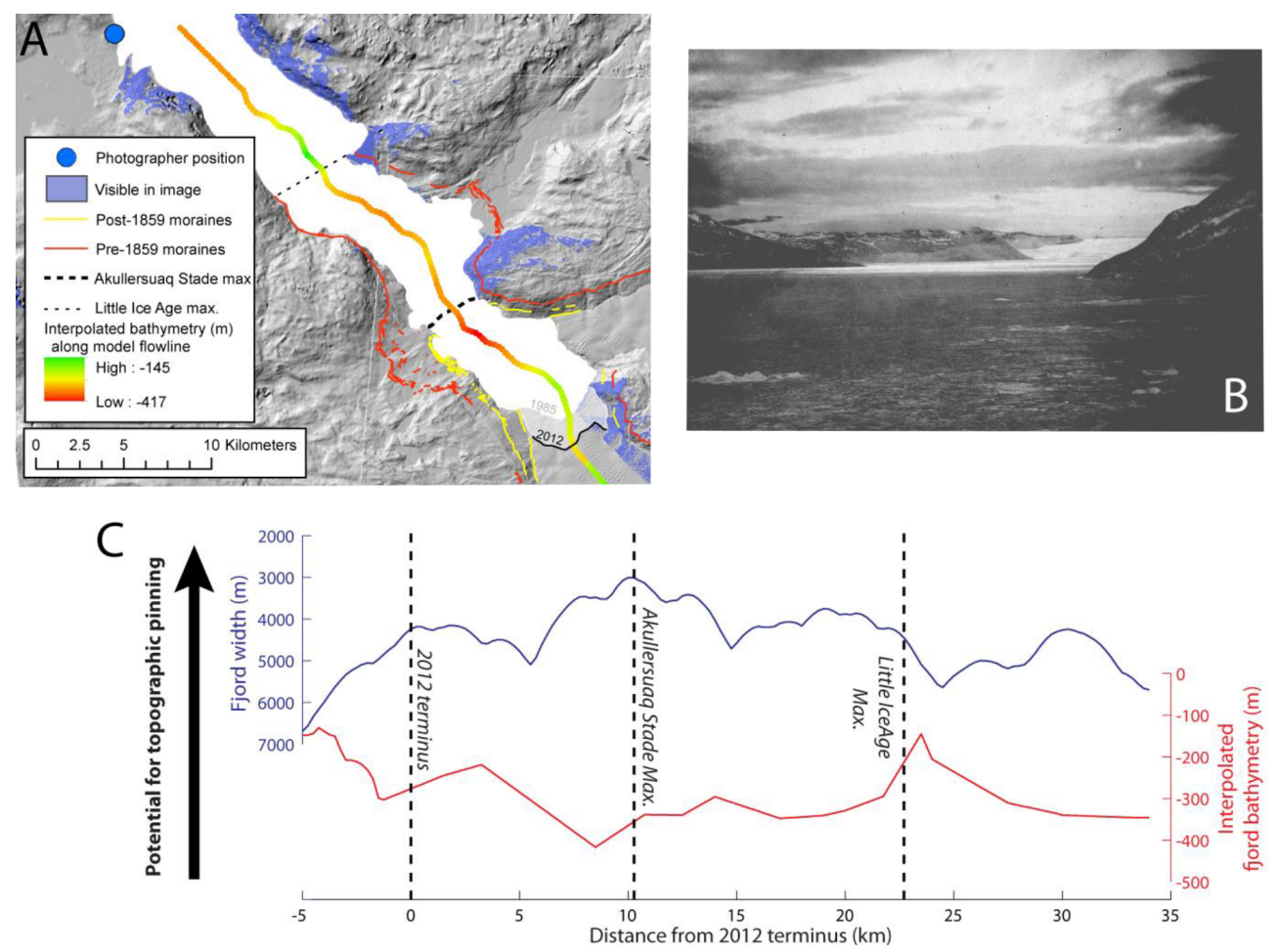

Figure 3. Viewshed analysis. (a) 1985 hillshaded DEM (see Fig. 1), with reconstructed photographer position showing areas that would be observable in the photograph, and the path of the model flow line showing the interpolated fjord bathymetry; (b) the photograph of KNS acquired in 1903; and (c) along-fjord width and depth relative to the 2012 terminus position. Note that fjord width is plotted on a reversed axis to reflect the relative potential for the occurrence of topographic pinning points.

is removed, meaning that $d_{\mathrm{w}}$ needs to be scaled to reflect this. Modelled annual runoff totals for each catchment show that KNS and AS respond directly in phase with one another $(r=0.99)$, with KNS accounting for $70.3 \%$ (MARv3.2) or $74.6 \%$ (RACMO2) of total runoff (Van As et al., 2014). To allow for this reduction in runoff as KNS retreats through the confluence, the value of $d_{\mathrm{w}}$ is multiplied by a scale factor, $\gamma$, that will have a fixed value for each model run of between $\alpha_{2}$ (a confluence scaling factor) and 1 , such that

$d_{\mathrm{wNew}}=\gamma d_{\mathrm{wPrev}}$.

Because AS and KNS will at times be partially confluent, the value of $\gamma$ is also scaled linearly with respect to the relative position of the terminus through the confluence, such that $\gamma=1$ when they are fully confluent, and $\gamma=\alpha_{2}$ when fully diffluent. Values are varied linearly between $\alpha_{2}$ and 1 for terminus positions within the confluence according to

$\gamma=\alpha_{2}+\left(1-\alpha_{2}\right)\left(\frac{x_{\mathrm{conf}}}{X_{\mathrm{conf}}}\right)$,

where $x_{\text {conf }}$ is the distance of the terminus through the confluence and $X_{\text {conf }}$ is the total flow-line distance over which the confluence occurs. Due to uncertainty regarding the precise scaling of runoff to $d_{\mathrm{w}}$ as KNS retreats through its confluence with AS, as well as other confluence effects, $\alpha_{2}$ is used as a tuning parameter within the model.

The extra ice flux contribution from AS when confluent with KNS is estimated to be approximately one-sixth of that of KNS, based on the contemporary across-glacier velocity profiles (Joughin et al., 2010) and terminus widths of AS and KNS. This extra flux is added to the modelled glacier as positive SMB at the confluence of KNS and AS, distributed along the flow line proportionate to the contemporary AS acrossglacier velocity profile (Lea et al., 2014a).

\subsection{Relating submarine melt to sea surface temperature}

Submarine melt rate $(M)$ has previously been linearly related to deep-ocean temperature (DOT) variability using a scaling coefficient (Nick et al., 2013, their Eq. S2). Using this parameterisation, the highest values of $M$ (expressed in this study in $\mathrm{km}^{3} \mathrm{a}^{-1}$ ) are associated with the highest scaling coefficients. Therefore high scaling factor values would also be linked to the highest inter-annual variability of $M$. This study takes a slightly different approach in that (1) $M$ is scaled to SST rather than DOT, for reasons relating to fjord circulation explained above, and (2) we introduce a constant (minimum) baseline $M$ rate, $M_{\text {base }}$, which is added to the linear relation with SST. We therefore calculate $M\left(\mathrm{~km}^{3} \mathrm{a}^{-1}\right)$ according to 
$M=M_{\text {base }}+\alpha_{3} T_{\text {year }}$,

where $\alpha_{3}$ is a submarine melt rate scaling coefficient, and $T_{\text {year }}$ is the annual average SST. This allows for multiple minimum background rates $M_{\text {base }}$ to be tested for different model runs, with various sensitivities of $M$ to changes in SST superimposed upon this using $\alpha_{3}$.

\subsection{Model experiments and evaluation}

Tuning parameters $\alpha_{1}, \alpha_{2}, \alpha_{3}$, and $M_{\text {base }}$ were varied randomly within prescribed limits for a total of 1500 Monte Carlo-style model runs. These were defined at the start of each run's spin-up period and held constant throughout. The limits for each of the tuning parameters were (1) $\alpha_{1}$, between 0 and 1.5 ; (2) $\alpha_{2}$, between 0.3 and 0.8 ; (3) $M_{\text {base }}$, between 0 and $0.7 \mathrm{~km}^{3} \mathrm{a}^{-1}$; and (4) $\alpha_{3}$, between 0 and 0.3 . These ranges of $\alpha_{1}$ and $\alpha_{2}$ were chosen to reflect a wide range of potential forcing scenarios, while the values of $M_{\text {base }}$ and $\alpha_{3}$ were chosen so total submarine melt rates could potentially range from $0 \mathrm{~km}^{3} \mathrm{a}^{-1}$ to values that exceed those estimated for other TWGs in western Greenland (Rignot et al., 2012; Enderlin and Howat, 2013). This allowed for the different potential drivers of the observed terminus change to be comprehensively assessed. Runs were conducted for the period 1871-2012, given that this is the period when both atmospheric and oceanic climate records are available. The model was initialised at approximately the ASM profile and terminus position, as defined by the geomorphology, and given the duration of the spin-up period to stabilise for the given forcing scenario. During spin-up, $d_{\mathrm{w}}$ was allowed to freely evolve by up to $\pm 3 \mathrm{~m} \mathrm{a}^{-1}$ to allow for the terminus to stabilise at the ASM, with $R_{\text {base }}$ and $T_{\text {year }}$ held constant. These were defined as the $1871-1920$ runoff average $\left(3.107 \mathrm{Gt} \mathrm{yr}^{-1}\right)$ and SST average $\left(2.605^{\circ} \mathrm{C}\right)$ respectively. These values were used for spin-up as it is known the ASM was attained at some point within this time window.

Model results were evaluated against their ability to replicate observed terminus dynamics, where absolute terminus positions are known (i.e. 1921 to 2012). The period from 1871 to 1920 therefore effectively becomes a transient spinup period, where the model is driven using real climate data, though terminus position is only known within a range. The ability of each model run to replicate observed dynamics was determined using a weighted regression $\left(R^{2}\right)$ calculation, with the weighting of each terminus observation calculated according to

$w_{n}=\frac{D_{n+1}-D_{n-1}}{2\left(D_{k}-D_{1}\right)}$ for $n=1,2, \ldots, k$,

where $w$ is the observation weighting in the regression calculation, $n$ is the terminus observation, $k$ is the total number of terminus observations, and $D$ is the date of the terminus observation. Each terminus observation is therefore temporally weighted according to the median length of time elapsed between the terminus observations that occur before and after observation $n$. This ensures that the evaluation of model performance is not biased towards the last $\sim 20$ years, where there is a comparatively high density of observations. Model runs were counted as successful where (1) the difference between the modelled and observed 1921 position was $<500 \mathrm{~m}$, (2) the weighted $R^{2}$ was $>0.85$, and (3) the gradient of the resulting line of regression was $>0.85$.

\section{Glacier reconstruction results}

The geomorphology shows distinct upper and lower sets of lateral moraines on both sides of the fjord, with fluted moraines occupying the intervening space (Fig. 1a). The upper set are associated with the LIA maximum (Lea et al, 2014a), while the lower set were formed during the Akullersuaq Stade. Fridtjof Nansen's (1890) account of the first traverse of Greenland in 1888 includes a drawing from a photograph showing AS and KNS to be confluent, though the terminus position itself is not visible. Although the original image could not be traced or an exact date of acquisition determined, it is likely to have been taken some time near to the publication date of 1890 .

Maps from 1859, 1860, 1866, and 1885 all show the terminus of KNS to be adjoining Akullersuaq and fully confluent with AS (Kleinschmidt, 1859; Poulsen, 1860; Brede, 1866; Rink, 1866; Jensen, 1885). While it is possible that some details on the maps were copied following Kleinschmidt (1859), the addition of detail such as lakes on plateaus near to KNS by Jensen (1885) provides confidence that this map faithfully records the contemporary terminus position. There is nothing to suggest that KNS became diffluent from AS at any time from 1859 to 1885 . However, due to a lack of map detail and the Nansen (1890) drawing not including the terminus, these sources cannot be used to provide absolute terminus positions.

The earliest images of KNS are from the 1850s and 1903. Both are taken from approximately the same position, with the terminus partially obscured by foreground topography (Weidick et al., 2012). The presence of medial moraines in each image demonstrates that KNS was confluent with AS. Lea et al. (2014a) quantified the terminus position uncertainty for the 1850 s photograph using viewshed analysis. Similar analysis has been undertaken for the 1903 image, showing that the uncertainty in terminus position is the same as for the 1850s image (Fig. 3). The maximum terminus extents for both images are therefore located behind a headland corresponding to the ASM on the eastern side of the fjord (Figs. 1a, 3).

It is not currently possible to say from any observational evidence when the ASM was attained, only that it occurred sometime between 1859 and 1920. The climate anomalies for the period (compared to 1961-1990 baselines) show that 


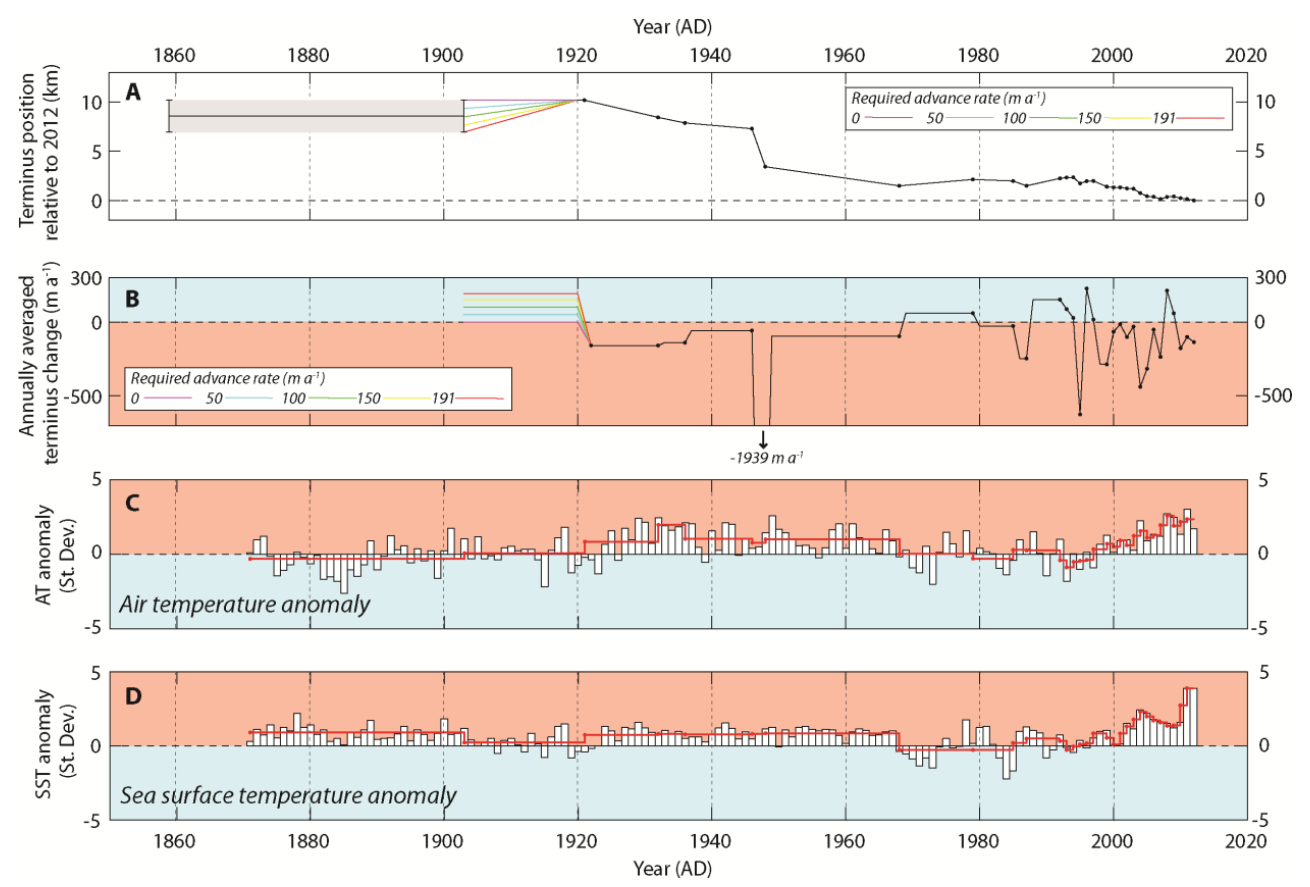

Figure 4. (a) Terminus change relative to the 2012 terminus position. Uncertainty in terminus position for 1859-1903 highlighted in grey, with a range of potential advance rates for 1903-1920 indicated. These range from a minimum of no change $\left(0 \mathrm{ma}^{-1}\right)$ to a maximum possible advance rate of $191 \mathrm{~m} \mathrm{a}^{-1}$. (b) Annually averaged rates of terminus change between observations (black dots). Includes terminus advance rates described for 1903-1921 terminus change indicated on A. (c) Summer AT anomaly (June-July-August) at annual resolution (white bars), and red line showing the averaged AT anomaly between terminus observations (Cappelen et al., 2012; Vinther et al., 2006). (d) Annual SST anomaly for the area 61 to $6^{\circ} \mathrm{N}, 51$ to $56^{\circ} \mathrm{W}$ at annual resolution (white bars) with red line showing the averaged SST anomaly between terminus observations (Rayner et al., 2003).

air temperature (AT) and SST anomalies were, on average, anti-phased for the period 1871-1903 (Fig. 4c, d), though AT and SST anomalies are in phase (negative/near-baseline) for 1903-1920. Conditions are therefore more likely to have been conducive for glacier advance during the latter period.

Terminus position was mapped directly for the remaining images, providing a record of 29 terminus positions spanning the period 1921-2012 (Figs. 1 and 4). The first direct terminus observation (1921) shows a slight retreat from the ASM. Subsequent to this, KNS retreated a total of $9.7 \mathrm{~km}$ at a nonuniform rate up to 2012, interrupted by short periods of readvance (Fig. 4a, b). Averaged retreat rates of $-116 \mathrm{~m} \mathrm{a}^{-1}$ are observed between 1921 and 1946, before a rapid retreat of $3.9 \mathrm{~km}$ within the 2-year period from 1946 to 1948 (Figs. 1a, 4). Between 1948 and 1968 KNS retreated on average by $-97 \mathrm{~m} \mathrm{a}^{-1}$, before readvancing by $+60 \mathrm{ma}^{-1}$ up to 1979 (Fig. 4b). A terrestrial photograph taken in 1965 with the majority of the terminus obscured shows the termini of KNS and AS to be fully diffluent.

The 1921-1968 period of sustained retreat was accompanied by positive average AT and SST anomalies (Fig. 4c, d). The highest AT anomalies occurred during the period 19281941, though the largest retreat (between 1946 and 1948) occurred during a comparatively less extreme period of positive AT and SST (Fig. 4).

From 1979 to $1987 \mathrm{KNS}$ retreated by $-658 \mathrm{~m}$ in total $\left(-82 \mathrm{~m} \mathrm{a}^{-1}\right)$, before readvancing by $+758 \mathrm{~m}$ from 1987 to $1992\left(+152 \mathrm{~m} \mathrm{a}^{-1}\right)$. Using the near-complete 20 -year annual record of terminus fluctuations from 1992 to 2012, KNS advanced for 4 out of 5 years between 1992 and 1997, followed by retreat in 11 out of 13 years from 1999 to 2012 at an average rate of $-103 \mathrm{ma}^{-1}$. The latter included eight annual retreats of $>100 \mathrm{~m}$, with the largest retreats occurring in $2004(-438 \mathrm{~m})$ and $2005(-316 \mathrm{~m})$. These periods of advance and retreat behaviour occurred during periods of inphase negative and positive climate anomalies respectively.

Where temporal density of observations was high, terminus behaviour that was anti-phased with the prevailing climate anomalies was also observed (i.e. advancing during positive temperature anomalies, or retreating during negative temperature anomalies). Examples of this include a retreat of $-626 \mathrm{~m}$ in 1995, when both climate anomalies were negative, while terminus advances occur in 2008 and 2009 despite markedly positive AT and SST anomalies (Fig. 4). At annual resolution, the magnitude of terminus retreat/advance was also found to be unrelated to the magnitude of either climate anomaly for each particular year. 


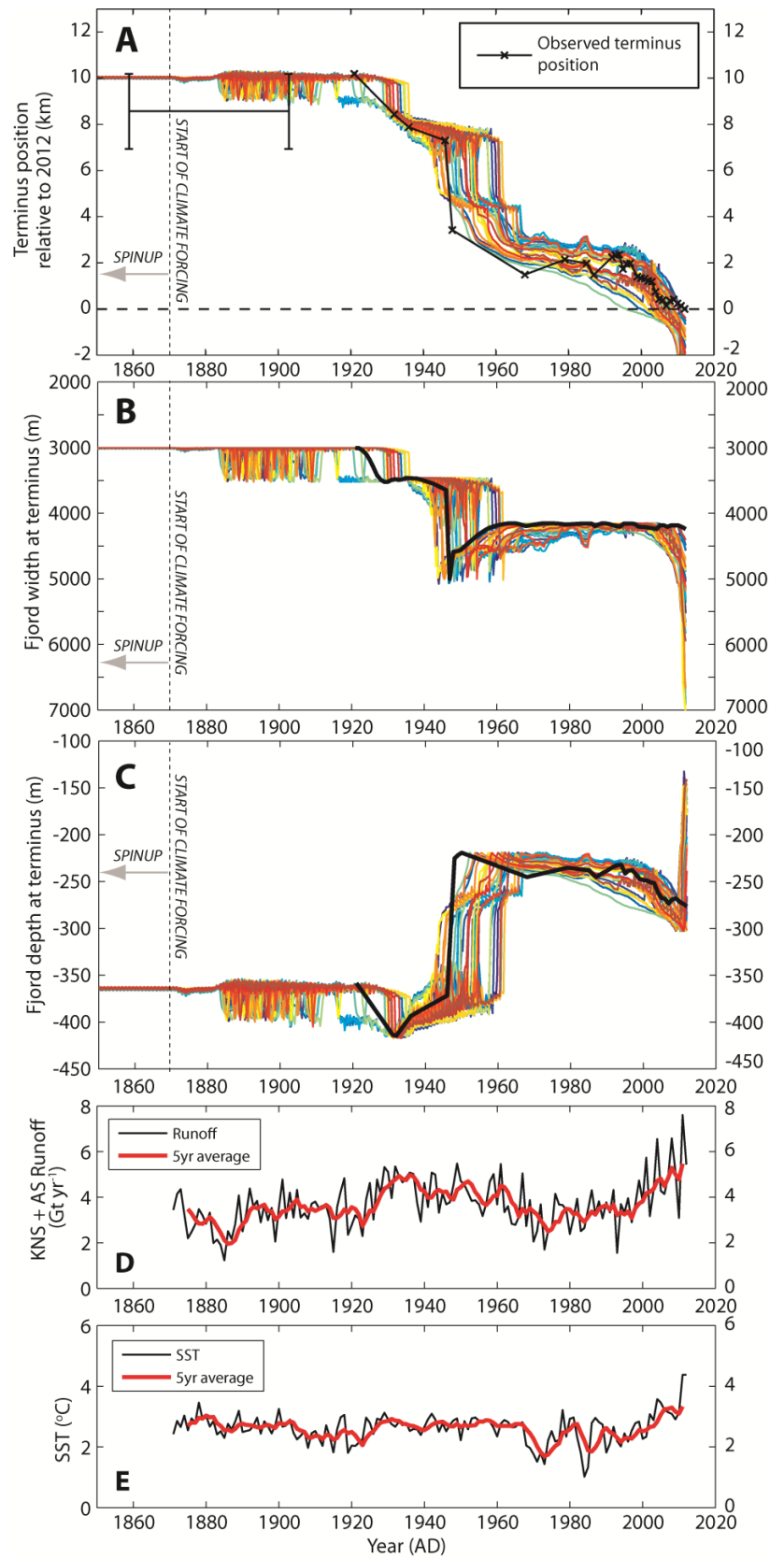

Figure 5. (a) Evolution of terminus position for model runs (coloured lines) determined to be successful according to the criteria outlined in the text, with observed terminus position also plotted (bold black line, with positions between observations linearly interpolated). (b) Evolution of fjord width at the terminus, with values interpolated from observations plotted in black. (c) Evolution of fjord depth at the terminus, with values interpolated from observations plotted in black. (d) Combined KNS and AS runoff volume estimates for 1871-2012 that are used to drive the model (5-year moving average also plotted in red). (e) Absolute annual SST estimates used to drive the model from Rayner et al. (2003) for the area 61 to $65^{\circ} \mathrm{N}$ and 51 to $56^{\circ} \mathrm{W}$ (5-year moving average also plotted in red).
Based on interpolated terminus positions between observations, terminus widths were consistent at $\sim 3.5 \mathrm{~km}$ from 1932 to 1946 , and $\sim 4.2 \mathrm{~km}$ from 1968 to 2012 , when terminus change was comparatively slow (Fig. 5b). Although fjord depths at the terminus for these periods were more variable, they did not exceed a range of $\pm 22 \mathrm{~m}$. Fjord width and depth at the terminus displayed two step changes during the retreats between 1921 and 1932 and between 1946 and 1948 (black lines, Fig. 5a-c). During the first of these, both width and depth increased (by $\sim 550$ and $44 \mathrm{~m}$ respectively), whereas width increased but depth decreased during the second (by $\sim 700 \mathrm{~m}$ and $146 \mathrm{~m}$ respectively).

\section{Model results}

From a total of 1500 model runs conducted, 29 runs (1.9\%) successfully replicated the observed dynamics of KNS according to the criteria outlined above (Fig. 5). Following the initiation of climate forcing in 1871 (Fig. 5d, e), the results of each run are highly comparable up to 1884 , with little modelled terminus change observed. Following this, for the period 1884 to $\sim 1910,6$ of the 29 runs $(21 \%)$ show evidence of multi-annual terminus retreats and equivalent readvances of $>750 \mathrm{~m}$ with periodicities of $2-4$ years. A further seven runs $(24 \%)$ show evidence of at least one short-lived $(<5$ year) oscillation in terminus position of $>750 \mathrm{~m}$ between 1884 and 1920. None of these model runs significantly exceed the ASM position, and thus they are in agreement with the geomorphological evidence presented, as well as the position of the 1921 terminus observation.

All model runs retreat to the observed 1932 position between modelled years 1929 and 1936, via a single retreat event of $\sim 1 \mathrm{~km}$. Subsequent to this, modelled retreat to the observed 1946 position is gradual, before the model successfully replicates a large topographically controlled retreat from the 1946 position. There was varying success in modelling the exact timing of this retreat (observed between 1946 and 1948), with the model ensemble predicting it to occur anywhere between 1943 and 1962. The position where the modelled terminus restabilises following the retreat through the AS confluence is generally too far advanced by $\sim 1 \mathrm{~km}$ compared to the position following the 1946-1948 retreat. All model runs then go on to over-predict terminus extent for the 1968 observation by between 0.35 and $1.59 \mathrm{~km}$.

Though no model runs exactly match the precise interannual terminus fluctuations from 1968 to 2012, they do capture the general multi-annual to decadal pattern of retreat observed. This is characterised by general terminus stability within a range of $\pm 500 \mathrm{~m}$ for the period 1968 to $\sim 1999$, before the terminus begins to retreat $\sim 2 \mathrm{~km}$ towards the 2012 position. All of the successful model runs identified predict KNS to be in a more retreated position in 2012 than observed by a range of 0.32 to $5.04 \mathrm{~km}$. 

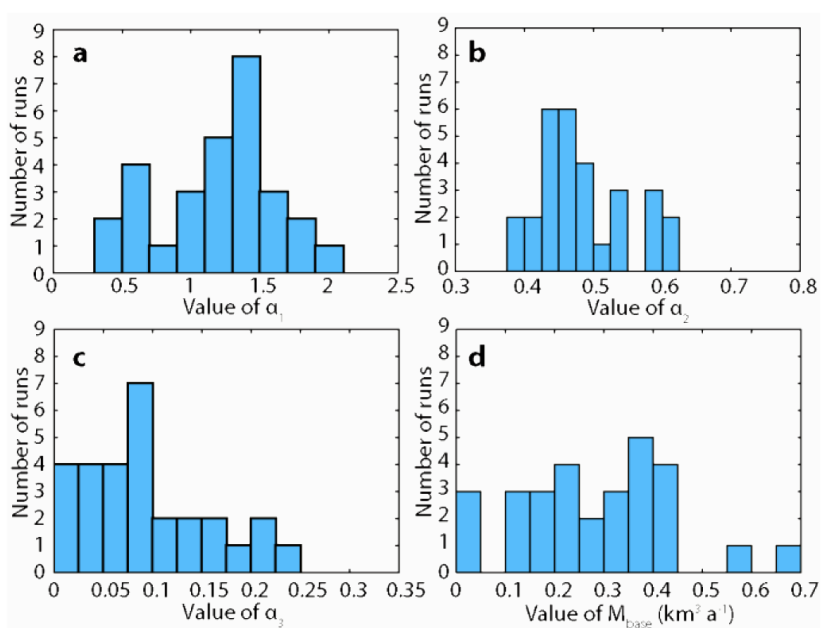

Figure 6. The distribution of the tuning parameters (a) $\alpha_{1}$ (bin width: 0.2), (b) $\alpha_{2}$ (bin width: 0.025), (c) $\alpha_{3}$ (bin width: 0.025), and (d) $M_{\text {base }}$ (bin width: $0.05 \mathrm{~km}^{3} \mathrm{a}^{-1}$ ) for successful runs as defined by the criteria outlined in the text. Minimum and maximum $x$-axis values represent the full range of values tested within the 1500 model runs.

Where a significant difference between observed and modelled terminus positions has occurred by the end of the model run in 2012, the divergence begins in 2010 at the earliest. This coincides with a widening of the modelled fjord associated with the uncertainty in fjord topography upstream of the contemporary terminus (Fig. 5b).

The distributions of tuning parameters for successful runs are shown in Fig. 6, with the distribution of all histograms shown to be non-normal. Submarine-melting-related tuning parameters $\alpha_{3}$ and $M_{\text {base }}$, tended towards the mid- to lower ends of the ranges tested (Fig. 6c, d). Values of $\alpha_{3}$ peak between 0.075 and 0.1 , though there is no clearly defined peak in the distribution of $M_{\text {base }}$ values.

In contrast, none of the $d_{\mathrm{w}}$-related tuning parameters $\left(\alpha_{1}\right.$ and $\alpha_{2}$ ) approach 0 (Fig. 6a, b), with the lowest values being 0.412 and 0.389 respectively. Construction of a correlation matrix comparing all tuning parameter values for all successful runs also demonstrates a significant inverse relationship between the value of $\alpha_{1}$ and the AS confluence parameter, $\alpha_{2}(r=-0.92)$. While other significant correlations are observed (Table 3 ), these are not of sufficient strength to allow for confident conclusions to be drawn.

\section{Discussion}

\subsection{Observed terminus behaviour}

From 1903 to 2012 AT and SST anomalies covaried, with the terminus generally undergoing retreat during periods of positive anomalies and advancing/stabilising when near/below baseline climate (Fig. 4). Exceptions to this
Table 3. Pearson correlation coefficient values for tuning parameters of successful model runs $(n=29)$. Correlation coefficients with $p$ values $<0.05$ are highlighted in bold.

\begin{tabular}{lrrrr}
\hline & $\alpha_{1}$ & $\alpha_{2}$ & $\alpha_{3}$ & Mbase \\
\hline$\alpha_{1}$ & - & $\mathbf{- 0 . 9 2 2 8 5}$ & 0.287883 & $\mathbf{- 0 . 4 6 8 8 4}$ \\
$\alpha_{2}$ & $\mathbf{- 0 . 9 2 2 8 5}$ & - & $\mathbf{- 0 . 4 6 0 6 5}$ & 0.292157 \\
$\alpha_{3}$ & 0.287883 & $-\mathbf{0 . 4 6 0 6 5}$ & - & $-\mathbf{0 . 4 2 7 1 1}$ \\
Mbase & $\mathbf{- 0 . 4 6 8 8 4}$ & 0.292157 & $\mathbf{- 0 . 4 2 7 1 1}$ & - \\
\hline
\end{tabular}

in-phase behaviour were only identified for the period 19922012, when a higher temporal density of terminus observations exists. However, by averaging annual observations over periods of sustained negative (1987-1997) and positive (1998-2012) climate anomalies, the terminus responds in phase with the climate anomalies. This demonstrates the risks of using short data sets ( $2-5$ years) to determine how a TWG is responding to climate forcing, highlighting the inherent noisiness, potential importance of antecedence, and the non-linearity of TWG response to climate.

A notable caveat to this occurs where significant topographically controlled glacier retreats occur (i.e. those driven by changes in fjord width and/or depth). These events could potentially skew annually averaged terminus change rates when attempting to characterise terminus response to climate forcing. The relative importance of this will be entirely dependent on the magnitude of individual events, and most significant where there is potential for multi-kilometre topographically controlled retreat. For example, if the 1946-1948 retreat event was not temporally well constrained, it could have significantly biased the terminus change rate values between 1936 and 1968 (Fig. 4b).

The 1946-1948 retreat occurs where the fjord widens and shallows at the terminus, while the 1921-1932 retreat is associated with a fjord widening and deepening (Fig. 5a-c). The 1946-1948 retreat is therefore likely to have been controlled by changes in lateral topography rather than basal topography, whereas the 1921-1932 retreat (if it occurred rapidly, e.g. in 1-2 years) likely resulted from a combination of both. In the periods between these $>1 \mathrm{~km}$ retreats, both fjord width and depth at the terminus remained largely consistent (Fig. 5b, c). While kilometre-scale, rapid retreat of KNS is likely due to a combination of retreat into fjord widenings or deepenings (e.g. Mercer, 1961; Carr et al., 2013, 2014; Porter et al., 2014), the 1946-1948 retreat helps to demonstrate that destabilising changes in one aspect of fjord topography can dominate stabilising changes in the other, until a new equilibrium is reached.

Since TWGs exhibit varying degrees of non-linearity in response to climate forcing, the identification of where and when these rapid multi-kilometre retreat events occur is crucial for interpreting the causes of terminus fluctuations. Where comparatively smaller (i.e. $<500 \mathrm{~m}$ ) climatically 
anti-phased advance/retreat events occur, their effect on average terminus change rates can be mitigated by averaging change over timescales up to or greater than a decade. For example, extending the $1992-1997$ average $\left(51 \mathrm{~m} \mathrm{a}^{-1}\right.$ retreat) to cover the period 1987-1997 (91 $\mathrm{m} \mathrm{a}^{-1}$ advance) provides a more representative impression of multi-annual terminus behaviour, since five out of the six observations available show terminus advance. Where observations are separated by $>1$ year, interpreting the absolute values of terminus change rates should therefore be done with caution. In most cases these values will be more representative of the average direction (i.e. advance/retreat), rather than the average distance of terminus change.

With uncertainties due to topographic controls on terminus stability taken into account, observations of terminus change over a period of several years provide a better indication of a TWG's response to climate forcing. However, for this study, deconvolving the relative importance of AT versus SST in driving terminus change is difficult using observations alone, given that both climate drivers vary in phase for 1903-present. It could potentially be argued that AT is the primary driver of change, since the 33-year period of positive anomaly SST from 1871 to 1903 had relatively little impact on the terminus stability of KNS. However, a narrow and relatively shallow fjord geometry in this region could also have been a significant factor in stabilising the terminus during this time (Fig. 3c). Arguably this becomes less likely when it is considered that, while SST was similar for the period 1921-1948, positive AT allowed for KNS to retreat through the same section of fjord and through its confluence with AS within $26 \pm 1$ years (Fig. 4). However, given the lack of certainty in terminus position between 1871 and 1920, it is not possible to robustly verify these arguments.

\subsection{Implications of modelling}

The observed terminus behaviour of KNS from 1921 to 2012 was successfully replicated by 29 of 1500 model runs using surface runoff and SST records as drivers of terminus change. This demonstrates that the parameterisations used to scale these climate records to $d_{\mathrm{w}}$ and $M$ respectively can successfully be used to simulate the observed pattern of tidewater glacier behaviour over centennial timescales. Where the observational record is of sufficient detail to resolve interannual terminus fluctuations (1992-2012), the model does not replicate these. This is to be expected given (1) the flowband nature of the model and associated depth and width integrations over each grid cell, meaning that fluctuations of terminus configurations such as the creation of calving bays cannot be replicated (e.g. Fig. 1b); (2) the uncertainty in fjord bathymetry and geometry potentially affecting relative terminus stability; and (3) the use of single terminus observations as notionally definitive indicators of annual terminus change, where the stochastic nature of calving and associated sub-annual terminus fluctuations make any direct one-to-one comparisons to modelled results inappropriate. Valid comparison of model results to observations should therefore only be attempted over multi-annual timescales where terminus dynamics within calving bays, sub-annual calving events and fine-scale uncertainties in fjords, and basal topography become comparatively less significant.

For successful model runs, the interrelationships between the parameter values that determine $d_{\mathrm{w}}$ and $M$ sensitivity to the climate records also inform the relative importance of changes in atmospheric and oceanic forcing in driving terminus change. The lack of any significant relationship between $\alpha_{1}$ and $\alpha_{3}$ demonstrates that a change in model sensitivity to surface runoff is not offset by any change in model sensitivity to SST (e.g. a higher $\alpha_{1}$ would not need to be offset by a lower $\alpha_{3}$ for the model run to match observations). Taken alone, this evidence indicates that either atmospheric forcing (via surface runoff) dominates oceanic forcing (via SST) or vice versa. However, the occurrence of runs where $\alpha_{3}$ does not significantly exceed 0 (i.e. where runs experience negligible $M$ variability) demonstrates that the model can successfully reproduce observed behaviour with nearly no changes in oceanic forcing from year to year. Although some successful model runs did have significant inter-annual $M$ variability (e.g. the maximum range of $M$ values for an entire 141-year model run was $0.76 \mathrm{~km}^{3} \mathrm{a}^{-1}$ ), each model run always requires significant atmospheric forcing variability to allow for it to replicate observations. The importance of oceanic forcing variability can therefore not be entirely discounted.

The model demonstrates that knowledge of atmospheric forcing (via runoff), without needing to vary oceanic forcing, can be sufficient to reproduce realistic patterns of observed glacier behaviour at KNS over the last century. However, the precise physical mechanism by which air temperature could drive observed change requires further investigation. For example, though a combination of modelled and empirically estimated runoff values has been used to drive changes in $d_{\mathrm{w}}$ to force the model, subglacial runoff variability is also known to drive rates of submarine melting at the terminus (Jenkins, 2011; Xu et al., 2012; Sciascia et al., 2013). Therefore we do not rule out that the behaviour observed could also be explained by calving driven by seasonal changes in submarine melt rates, which are in turn a function of subglacial runoff (e.g. Sciascia et al., 2013).

The relative insensitivity to changes in oceanic forcing is not necessarily surprising given the hydrographic setting of KNS - located at the end of a $>100 \mathrm{~km}$ long fjord system that is thought to be largely insulated from changes in ocean conditions due to the presence of a shallow sill at its entrance (Mortensen et al., 2011, 2013). This has previously been used to suggest that recent changes in ocean conditions (e.g. Straneo and Heimbach, 2013) have not affected the dynamics of KNS significantly (Straneo et al., 2012). The results presented here are therefore compatible with this argument. 
The overestimation of terminus retreat by 2012 of every successful run is thought to result from the poor knowledge of fjord width geometry beyond the contemporary glacier terminus. Upstream of the 2012 terminus, the lateral ice margins are used to define model glacier width, leading to a likely overestimation of the prescribed fjord width. The divergence between the actual and prescribed fjord width is likely to increase upglacier, increasing the likelihood of model error in this area. This explains why significant divergence from the observational record only occurs once the modelled terminus has retreated $\sim 1.5 \mathrm{~km}$ beyond the 2012 terminus (Fig. 5a-c). Given the shallowing of the fjord bathymetry upstream of the 2012 terminus (Fig. 5c), fjord width uncertainty is likely to be the major cause of the model overestimating retreat (Fig. 5b). This also substantiates observations that destabilising changes in fjord width can dominate stabilising changes in fjord depth. Any attempt at modelling the future fluctuations of KNS will therefore require both improvements to subglacial topography estimates and comprehensive assessments of fjord width uncertainties as part of any predictions.

\section{Conclusions}

Utilising multiple lines of evidence, it has been possible to reconstruct terminus fluctuations of KNS from 1859 to 2012. This study therefore completes the record of terminus fluctuations of KNS from its LIA maximum, in 1761 (Lea et al., 2014a), up to the present, providing one of the longest and most detailed records of observed TWG change in Greenland. The length and detail of this record, in conjunction with existing data sets providing boundary conditions, therefore make KNS an ideal validation site for models aiming to simulate outlet glacier retreat and/or the impact of calving on tidewater glacier dynamics. At present the major boundary condition uncertainty is fjord topography, though what is known is sufficient for the model used in this study to replicate observed dynamics over multi-decadal to centennial timescales.

Results from numerical modelling show that the fluctuations of KNS can be simulated through parameterisations that link surface runoff to a crevasse-water-depth-based calving criterion. Changes in crevasse water depth and/or runoffdriven rates of submarine melt are therefore suggested as potential drivers of observed change. Although ocean-driven changes in submarine melt rates are not always required for the model to replicate the observed length variations of KNS, results do not allow for their importance to be discounted entirely.

Observations of KNS show it to respond in phase with AT and SST anomalies over multi-annual to decadal timescales from at least 1921 to 2012 (i.e. retreating during positive temperature anomalies, and advancing during negative temperature anomalies). However, where inter-annual comparisons to AT and SST are possible (1992-2012), climatically anti-phased terminus fluctuations are observed. This highlights the inherent noisiness of terminus response over short timescales, the potential importance of antecedence, and the dangers of using similarly short calibration periods for predictive modelling efforts.

Results from numerical modelling successfully capture the terminus dynamics of KNS over multi-annual to decadal timescales, though not precise inter-annual fluctuations. This is due to a combination of uncertainties in fjord topography as well as the approximations inherent to the depth and width integrations associated with using a one-dimensional flowband model.

Nevertheless, this study demonstrates that simple flowband numerical models of tidewater glaciers can be used to capture TWG dynamics over multi-annual to centennial timescales. This provides validation that these models can be useful tools for palaeo-, contemporary, and prognostic modelling efforts. However, the primary challenge to their use as predictive tools remains the accurate definition of subglacial topography and fjord width, which exert dominant controls on glacier stability. Any future efforts at prognostic modelling of TWGs should therefore seek to account for these uncertainties in addition to those associated with sensitivity to climate forcing.

Acknowledgements. The authors wish to thank Stephen Price, Mauri Pelto, and the anonymous reviewer for their reviews and comments that helped to improve the manuscript. RACMO2.1 data were provided by Jan van Angelen and Michiel van den Broeke, IMAU, Utrecht University. MAR v3.2 data used for runoff calculations were provided by Xavier Fettweis, Department of Geography, University of Liège. The photogrammetric DEM used in Figs. 1 and 3 was provided by Kurt H. Kjær, Centre for GeoGenetics, University of Copenhagen. This research was financially supported by J. M. Lea's PhD funding, NERC grant number NE/I528742/1. Support for F. M. Nick was provided through the Conoco-Phillips/Lundin Northern Area Program CRIOS project (Calving Rates and Impact on Sea Level).

Edited by: H. Gudmundsson 


\section{References}

Ahlstrøm, A. P., Andersen, S. B., Andersen, M. L., Machguth, H., Nick, F. M., Joughin, I., Reijmer, C. H., van de Wal, R. S. W., Merryman Boncori, J. P., Box, J. E., Citterio, M., van As, D., Fausto, R. S., and Hubbard, A.: Seasonal velocities of eight major marine-terminating outlet glaciers of the Greenland ice sheet from continuous in situ GPS instruments, Earth Syst. Sci. Data, 5, 277-287, doi:10.5194/essd-5-277-2013, 2013.

Alley, R. B., Andrews, J. T., Brigham-Grette, J., Clarke, G. K. C., Cuffey, K. M., Fitzpatrick, J. J., Funder, S., Marshall, S. J., Miller, G. H., Mitrovica, J. X., Muhs, D. R., Otto-Bliesner, B. L., Polyak, L., and White, J. W. C.: History of the Greenland Ice Sheet: paleoclimatic insights, Quaternary Sci. Rev., 29, 17281756, doi:10.1016/j.quascirev.2010.02.007, 2010.

Bamber, J. L., Layberry, R. L., and Gogineni, S. P.: A new ice thickness and bed data set for the Greenland ice sheet: 1. Measurement, data reduction, and errors, J. Geophys. Res.-Atmos. (1984-2012), 106, 33773-33780, doi:10.1029/2001JD900054, 2001

Benn, D. I., Warren, C. R., and Mottram, R. H.: Calving processes and the dynamics of calving glaciers, Earth-Sci. Rev., 82, 143179, doi:10.1016/j.earscirev.2007.02.002, 2007.

Bevan, S. L., Luckman, A. J., and Murray, T.: Glacier dynamics over the last quarter of a century at Helheim, Kangerdlugssuaq and 14 other major Greenland outlet glaciers, The Cryosphere, 6, 923-937, doi:10.5194/tc-6-923-2012, 2012.

Bjørk, A. A., Kjær, K. H., Korsgaard, N. J., Khan, S. A., Kjeldsen, K. K., Andresen, C. S., Larsen, N. K., and Funder, S.: An aerial view of 80 years of climate-related glacier fluctuations in southeast Greenland, Nat. Geosci., 5, 427-432, doi:10.1038/ngeo1481, 2012

Brede, N.: Skizze Kaart over Vestkysten af Grönland fra Arsuk til Holsteensborg, KBK Netpublikation DK003200, Copenhagen, 1866.

Bruun, D.: Oversigt over Norburuiner i Godthaab og Frederikshaab Distrikter, Medelelser om Grønland, 56, 55-147, 1917.

Cappelen, J.: Greenland-DMI Historical Climate Data Collection 1873-2011, Technical Report 12-04, Copenhagen, ISSN: 13991388, 2012.

Carr, J. R., Vieli, A., and Stokes, C.: Influence of sea ice decline, atmospheric warming, and glacier width on marine?terminating outlet glacier behavior in northwest Greenland at seasonal to interannual timescales, J. Geophys. Res.-Earth, 118, 1210-1226, doi:doi:10.1002/jgrf.20088, 2013.

Carr, J. R., Stokes, C., and Vieli, A.: Recent retreat of major outlet glaciers on Novaya Zemlya, Russian Arctic, influenced by fjord geometry and sea-ice conditions, J. Glaciol., 60, 155-170, doi:10.3189/2014JoG13J122, 2014.

Colgan, W., Pfeffer, W. T., Rajaram, H., Abdalati, W., and Balog, J.: Monte Carlo ice flow modeling projects a new stable configuration for Columbia Glacier, Alaska, c. 2020, The Cryosphere, 6, 1395-1409, doi:10.5194/tc-6-1395-2012, 2012.

Cook, S., Zwinger, T., Rutt, I. C., O’Neel, S., and Murray, T.: Testing the effect of water in crevasses on a physically based calving model, Ann. Glaciol., 53, 90-96, doi:10.3189/2012AoG60A107, 2012.
Cook, S., Rutt, I. C., Murray, T., Luckman, A., Zwinger, T., Selmes, N., Goldsack, A., and James, T. D.: Modelling environmental influences on calving at Helheim Glacier in eastern Greenland, The Cryosphere, 8, 827-841, doi:10.5194/tc-8-827-2014, 2014.

Csatho, B., Schenk, T., Van der Veen, C. J., and Krabill, W. B.: Intermittent thinning of Jakobshavn Isbræ, West Greenland, since the Little Ice Age, J. Glacio., 54, 131-144, doi:10.3189/002214308784409035, 2008.

Enderlin, E. M. and Howat, I. M.: Submarine melt rate estimates for floating termini of Greenland outlet glaciers (2000-2010), J. Glaciol., 59, 67-75, doi:10.3189/2013JoG12J049, 2013.

Fettweis, X., Tedesco, M., van den Broeke, M., and Ettema, J.: Melting trends over the Greenland ice sheet (1958-2009) from spaceborne microwave data and regional climate models, The Cryosphere, 5, 359-375, doi:10.5194/tc-5-359-2011, 2011.

Gogineni, S., Tammana, D., Braaten, D., Leuschen, C., Akins, T., Legarsky, J., Kanagaratnam, P., Stiles, J., Allen, C., and Jezek, K.: Coherent radar ice thickness measurements over the Greenland ice sheet, J. Geophys. Res.-Atmos., (1984-2012), 106, 33761-33772, doi:10.1029/2001JD900183, 2001.

Hanna, E., Cappelen, J., Fettweis, X., Huybrechts, P., Luckman, A., and Ribergaard, M. H.: Hydrologic response of the Greenland ice sheet: the role of oceanographic warming, Hydrol. Process., 23, 7-30, 2009, doi:10.1002/hyp.7090, 2009

Howat, I. M. and Eddy, A.: Multi-decadal retreat of Greenland's marine-terminating glaciers, J. Glaciol., 57, 389-396, doi:10.3189/002214311796905631, 2011.

Hvidegaard, S. M., Sorensen, L. S., and Forsberg, R.: ASTER GDEM validation using LiDAR data over coastal regions of Greenland, Remote Sens. Lett., 3, 85-91, doi:10.1080/01431161.2010.527389, 2012.

Jamieson, S. S., Vieli, A., Livingstone, S. J., Cofaigh, C. Ó., Stokes, C., Hillenbrand, C. D., and Dowdeswell, J. A.: Ice-stream stability on a reverse bed slope, Nat. Geosci., 5, 799-802, 2012 , doi:10.1038/ngeo1600, 2012.

Jamieson, S. S. R., Vieli, A., Ó Cofaigh, C., Stokes, C. R., Livingstone, S. J., and Hillenbrand, C.-D.: Understanding controls on rapid ice-stream retreat during the last deglaciation of Marguerite Bay, Antarctica, using a numerical model, J. Geophys. Res.Earth Surf., 119, 247-263, doi:10.1002/2013JF002934, 2014.

Jenkins, A.: Convection-Driven Melting near the Grounding Lines of Ice Shelves and Tidewater Glaciers, J. Phys. Oceanogr., 41, 2279-2294, doi:10.1175/JPO-D-11-03.1, 2011.

Jensen, J. A. D.: Vestkysten af Grönland fra Arsuk til Holstensborg $61^{\circ}$ til $67^{\circ} \mathrm{N}, \mathrm{KBK}$ Netpublikation, DK003198, Copenhagen, 1885 .

Joughin, I., Smith, B. E., Howat, I. M., Scambos, T., and Moon, T.: Greenland flow variability from icesheet-wide velocity mapping, J. Glaciol., 56, 415-430, doi:10.3189/002214310792447734, 2010.

Kleinschmidt, S.: Godthåbs distrikt (hertil en Navneliste), (Map No. KBK Netpublikation RI000074), Copenhagen, 1859.

Lea, J. M., Mair, D. W. F., Nick, F. M., Rea., B. R., Weidick, A., Kjær, K., Morlighem, M., van As, D., and Schofield, J. E.: Terminus-driven retreat of a major southwest Greenland tidewater glacier during the early 19th century: insights from glacier reconstructions and numerical modelling, J. Glaciol., 220, 333 344, doi:10.3189/2014JoG13J163, 2014a. 
Lea, J. M., Mair, D. W. F., and Rea, B. R.: Evaluation of existing and new methods of tracking glacier terminus change, J. Glaciol., 220, 323-332, doi:10.3189/2014JoG13J061, 2014b.

McFadden, E. M., Howat, I. M., Joughin, I., Smith, B. E., and Ahn, Y.: Changes in the dynamics of marine terminating outlet glaciers in west Greenland (2000-2009), J. Geophys. Res.-Earth Surf. (2003-2012), 116, F02022, doi:10.1029/2010JF001757, 2011.

Moon, T. and Joughin, I.: Changes in ice front position on Greenland's outlet glaciers from 1992 to 2007, J. Geophys. Res.-Earth Surf. (2003-2012), 113, F02022, doi:10.1029/2007JF000927, 2008.

Morlighem, M., Rignot, E., Seroussi, H., Larour, E., Ben Dhia, H., and Aubry, D.: A mass conservation approach for mapping glacier ice thickness, Geophys. Res. Lett., 38, L19503, doi:10.1029/2011GL048659, 2011.

Mercer, J. H.: The response of fjord glaciers to changes in the firn limit, J. Glaciol., 3, 850-858, 1961.

Mortensen, J., Lennert, K., Bendtsen, J., and Rysgaard, S.: Heat sources for glacial melt in a sub-Arctic fjord (Godthåbsfjord) in contact with the Greenland Ice Sheet, J. Geophys. Res.-Oceans (1978-2012), 116, C01013, doi:10.1029/2010JC006528, 2011.

Mortensen, J., Bendtsen, J., Motyka, R. J., Lennert, K., Truffer, M., Fahnestock, M., and Rysgaard, S.: On the seasonal freshwater stratification in the proximity of fast-flowing tidewater outlet glaciers in a sub-Arctic sill fjord, J. Geophys. Res.-Oceans, 118, 1382-1395, doi:10.1002/jgrc.20134, 2013.

Murray, T., Scharrer, K., James, T. D., Dye, S. R., Hanna, E., Booth, A. D., Selmes, N., Luckman, A., Hughes, A. L. C., Cook, S., and Huybrechts, P.: Ocean regulation hypothesis for glacier dynamics in southeast Greenland and implications for ice sheet mass changes, J. Geophys. Res.-Earth Surf. (2003-2012), 115, F03026, doi:10.1029/2009JF001522, 2010.

Nansen, F.: The first crossing of Greenlandm Longmans, London, 1890.

Nick, F. M., Van der Veen, C. J., Vieli, A., and Benn, D. I.: A physically based calving model applied to marine outlet glaciers and implications for the glacier dynamics, J. Glaciol., 56, 781-794, doi:10.3189/002214310794457344, 2010.

Nick, F. M., Luckman, A., Vieli, A., Van der Veen, C. J., Van As, D., Van de Wal, R. S. W., Pattyn, F., Hubbard, A. L., and Floricioiu, D.: The response of Petermann Glacier, Greenland, to large calving events, and its future stability in the context of atmospheric and oceanic warming, J. Glaciol., 58, 229-239, doi:10.3189/2012JoG11J242, 2012.

Nick, F. M., Vieli, A., Andersen, M. L., Joughin, I., Payne, A., Edwards, T. L., Pattyn, F., and van de Wal, R. S.: Future sea-level rise from Greenland/'s main outlet glaciers in a warming climate, Nature, 497, 235-238, doi:10.1038/nature12068, 2013.

Pattyn, F., Schoof, C., Perichon, L., Hindmarsh, R. C. A., Bueler, E., de Fleurian, B., Durand, G., Gagliardini, O., Gladstone, R., Goldberg, D., Gudmundsson, G. H., Huybrechts, P., Lee, V., Nick, F. M., Payne, A. J., Pollard, D., Rybak, O., Saito, F., and Vieli, A.: Results of the Marine Ice Sheet Model Intercomparison Project, MISMIP, The Cryosphere, 6, 573-588, doi:10.5194/tc6-573-2012, 2012.

Porter, D. F., Tinto, K. J., Boghosian, A., Cochran, J. R., Bell, R. E., Manizade, S. S., and Sonntag, J. G.: Bathymetric control of tidewater glacier mass loss in northwest Greenland, Earth Planet. Sc. Lett., 401, 40-46, doi:10.1016/j.eps1.2014.05.058, 2014.
Poulsen, J.: Godthåb kommune, KBK Netpublikation RI000059, Copenhagen, 1860.

Rayner, N. A., Parker, D. E., Horton, E. B., Folland, C. K., Alexander, L. V., Rowell, D. P., Kent, E. C., and Kaplan, A.: Global analyses of sea surface temperature, sea ice, and night marine air temperature since the late nineteenth century, J. Geophys. Res.Atmos. (1984-2012), 108, 4407, doi:10.1029/2002JD002670, 2003.

Rignot, E., Fenty, I., Menemenlis, D., and Xu, Y.: Spreading of warm ocean waters around Greenland as a possible cause for glacier acceleration, Ann. Glaciol., 53, 257-266, doi:10.3189/2012AoG60A136, 2012.

Rink, H.: Kyststrækning fra Frederikshåb i syd til Napasaq i nord, KBK Netpublikation RI000029, Copenhagen, 1866.

Roussell, A.: Farms and Churches of the Medieval Norse Settlement in Greenland, Medelelser om Grønland, 89, 1-235, 1941.

Sciascia, R., Straneo, F., Cenedese, C., and Heimbach, P.: Seasonal variability of submarine melt rate and circulation in an East Greenland fjord. J. Geophys. Res.-Oceans, 118, 2492-2506, 2013, doi:10.1002/jgrc.20142, 2013.

Sole, A. J., Mair, D. W. F., Nienow, P. W., Bartholomew, I. D., King, M. A., Burke, M. J., and Joughin, I.: Seasonal speedup of a Greenland marine-terminating outlet glacier forced by surface melt-induced changes in subglacial hydrology, J. Geophys. Res.-Earth Surf. (2003-2012), 116, F03014, doi:10.1029/2010JF001948, 2011.

Straneo, F. and Heimbach, P.: North Atlantic warming and the retreat of Greenland's outlet glaciers, Nature, 504, 36-43, doi:10.1038/nature12854, 2013.

Straneo, F., Hamilton, G. S., Sutherland, D. A., Stearns, L. A., Davidson, F., Hammill, M. O., Stenson, G. B., and RosingAsvid, A.: Rapid circulation of warm subtropical waters in a major glacial fjord in East Greenland, Nat. Geosci., 3, 182-186, doi:10.1038/ngeo764, 2010.

Straneo, F., Sutherland, D. A., Holland, D., Gladish, C., Hamilton, G. S., Johnson, H. L., Rignot, E., Xu, Y., and Koppes, M.: Characteristics of ocean waters reaching Greenland's glaciers, Ann. Glaciol., 53, 202-210, doi:10.3189/2012AoG60A059, 2012.

Taurisano, A., Bøggild, C. E., and Karlsen, H. G.: A century of climate variability and climate gradients from coast to ice sheet in West Greenland, Geograf. Annal. Series A, 86, 217-224, doi:10.1111/j.0435-3676.2004.00226.x, 2004.

Van Angelen, J. H., van den Broeke, M. R., Wouters, B., and Lenaerts, J. T. M.: Contemporary (1960-2012) evolution of the climate and surface mass balance of the Greenland ice sheet, Surv. Geophys., 5, 1155-1174, doi:10.1007/s10712-013-9261-z, 2013.

Van As, D., Andresen, M. L., Petersen, D., Fettweis, X., van Angelen, J. H., Lenearts, J. T. M., van den Broeke, M. R., Lea, J. M., Bayou, N., Bøggild, C. E., Ahlstrøm, A. P., and Steffen, K.: Increasing meltwater discharge from the Nuuk region of the Greenland ice sheet and implications for mass balance (1960-2012), J. Glaciol., 220, 314-322, doi:10.3189/2014JoG13J065, 2014.

Van den Broeke, M., Bamber, J., Ettema, J., Rignot, E., Schrama, E., van de Berg, W. J., van Meijgaard, E., Velicogna, I., and Wouters, B.: Partitioning recent Greenland mass loss, Science, 326, 984 986, doi:10.1126/science.1178176, 2009. 
Vieli, A. and Nick, F. M.: Understanding and modelling rapid dynamic changes of tidewater outlet glaciers: issues and implications, Surv. Geophys., 32, 437-458, doi:10.1007/s10712-0119132-4, 2011.

Vinther, B. M., Andersen, K. K., Jones, P. D., Briffa, K. R., and Cappelen, J.: Extending Greenland temperature records into the late eighteenth century, J. Geophys. Res.-Atmos. (1984-2012), 111, doi:10.1029/2005JD006810, 2006.

Weidick, A. and Citterio, M.: The ice-dammed lake Isvand, West Greenland, has lost its water, J. Glaciol., 57, 186-188, 2011, doi:10.3189/002214311795306600, 2011.
Weidick, A., Bennike, O., Citterio, M., and Nørgaard-Pedersen, N.: Neoglacial and historical glacier changes around Kangersuneq fjord in southern West Greenland, Geological Survey of Denmark and Greenland. Copenhagen, ISBN:978-87-7871-3476, 2012.

$\mathrm{Xu}$, Y., Rignot, E., Menemenlis, D., and Koppes, M.: Numerical experiments on subaqueous melting of Greenland tidewater glaciers in response to ocean warming and enhanced subglacial discharge, Ann. Glaciol., 53, 229-234, doi:10.3189/2012AoG60A139, 2012. 